\title{
Analysis about Lower Growth Rate of Foreign Exchange Reserve's Impact on Domestic Money Supply
}

\author{
Zhang Sichen
}

Xidian University, Economy and Management School

\begin{abstract}
Under the New Normal Economy, GDP is no longer guaranteed $8 \%$ in China, and the potential growth rate will gradually decline to 7.5\%; macroeconomic policy will no longer use the past type of stimulus control; the economy won't adopt monetary-driven growth model which was frequently used before. Despite the fact that the total volume of foreign exchange reserves is still huge nowadays, with the acceleration of RMB internationalization, developed countries "deleveraging" one after another after the 2008 financial crisis and a increasingly stronger dollar, however, from the perspective of growth rate, foreign exchange reserves has already been on a path to "declining". Based on the Balance Sheet of Central Bank, this article analyzes the impact of lowering growth rate of foreign exchange reserves on money supply. For our country, funds outstanding for foreign exchange are no longer the main monetary distribution channel, monetary policy will be more dependent on new liquidity adjustment tools such as MLF, PSL, SLO etc. This study can be conducted in two aspects, one from monetary base, the other money multiplier, and some reasonable strategies like dredging credit transmission channels to reduce the time lag effect are given at the end of this paper.
\end{abstract}

Keywords: New Norm; Foreign Exchange Reserves; MoneySupply; Balance Sheet of Central Bank

\section{Introduction}

Undoubtedly, China's foreign exchange reserves have been growing rapidly since the reform of the foreign exchange system in 1994, which changed after the 2008 financial crisis. Although the total amount of foreign exchange reserves is still huge, in terms of the growth rate, it is already decelerating, presenting a new feature of "increase in total volume and slow growth". From the long term, if the trade surplus fell, the capital account deficit, depreciation anticipated intensifies, foreign exchange will no longer be put in the monetary base, the major source of monetary policy will rely more on MLF, PSL, SLO, SLF new liquidity adjustment tools, etc.

Monetary authorities are extremely concerned about changes in the foreign exchange reserves, because changes in them affect financial performance. In the increasingly open macroeconomic environment, this paper discusses the influence of foreign exchange for our money, find out the factors that play a key role and clarify the influence degree of these important factors on the money, is particularly important for monetary policy. In this paper, advancing with The Times, stick to the new normal economic background, from the perspective of the central bank's balance sheet, the influence of foreign exchange reserves to slow growth in the money supply, selected topic has certain theoretical and practical significance.

\section{Literature Review}

Most domestic scholars is foreign exchange reserves of the money supply affect the stock of this research mainly concentrated in the point of view, analysis method by theoretical analysis and empirical test, it is concluded that foreign exchange to bring was forced to drop the monetary base and points out that the coping strategies, studies of reserve accumulation is very little. Such as: SuQin (2013) in the monetary base and money multiplier as a starting point, in-depth analysis of foreign exchange how to affect the money supply in our country, finally it is concluded that under the condition of the money supply target established, a large amount of foreign exchange from the conclusion of the domestic credit. [1] Luo Gonghua (2014) to accounting perspective to interpret the essence of foreign exchange in our country and the countermeasures study, based on the flow direction of foreign exchange funds and GDP accounting products flow method, come to the conclusion that foreign exchange reserve monetary policy autonomy. Wang Xuan [2] (2014) based on between January 2006 and December 2006, foreign exchange and the monthly data of monetary base through variance decomposition, Granger causality test and VAR model to carry on the empirical analysis, test results show that the short-term foreign exchange has a significant effect on the monetary base.

Most of foreign scholars debate lies in how to construct foreign exchange for the country's money supply can be influence degree of a quantitative, foreign exchange on the impact of monetary policy is embodied in the foreign exchange market equilibrium point. First, Girton\&Roper put forward the Exchange Market Pressure. He used the balance of payments theory to construct the excess demand index of the currency by combining the simple monetary model. The premise of maintaining a currency equilibrium lies in adjusting the exchange rate or the change in the foreign exchange reserves or the two to eliminate the monetary imbalance. In terms of literature, the main use of metering models and empirical principles to study foreign exchange reserves, Kathryn M.E. Dominguez (2012) examined how countries manage their foreign exchange reserves during the global financial crisis. Evidence based on changes in reserve

Volume 6 Issue 12, December 2017 


\section{International Journal of Science and Research (IJSR) \\ ISSN (Online): 2319-7064}

Index Copernicus Value (2016): 79.57 | Impact Factor (2015): 6.391

inventories suggests that governments in many countries, even before the crisis, were reluctant to use them during crises. Data further shows that when a country before the crisis level of reserves of more than can be measured by the standard model of foreign exchange reserve accumulation, it is most likely to reserve assets sold during the financial crisis.

Based on domestic related literature of foreign exchange reserves is discussed, it can be seen that the main focus of research has focused on the hedging cost of excess foreign exchange reserves, foreign exchange reserves and monetary base on the correlation between written off, and foreign exchange on the impact of monetary policy, the influence of the huge foreign exchange reserves on the domestic economy and impact, etc. The research on the accumulation of foreign exchange reserves is less, and the background of The Times has changed, and the literatures are very few. In addition to the central bank balance sheet to master relevant knowledge but have higher requirements, must understand all items in the table, the corresponding relationship between analysis needs a lot of data to support, some of the latest data query and calculate it by ourselves. Thus the difficulty of this paper is to keep pace with The Times, based on the central bank balance sheets are analyzed under the new normal low impact on money supply growth in foreign exchange reserves, from two aspects of monetary base and money multiplier conduction of the foreign exchange reserves changes affect the money supply with the path and put forward the corresponding countermeasures.

\section{Framework of central bank balance sheet}

\subsection{The Composition of the Balance Sheet}

Central bank balance sheets are formed by the central bank for business activities report of creditor's rights debt, comprehensive reflects its assets business and liabilities business type, size and structure, is a country's monetary authorities to perform the functions of macro policy of the important basis. There are three asset businesses: foreign assets, domestic credit and other assets. Foreign assets are made up of foreign exchange reserves, currency gold, and other foreign assets. In the past, China has accumulated a large amount of foreign exchange under the compulsory sales and foreign exchange system, thus forming foreign exchange deposits. Domestic credit consists of two parts: one is the creditor's right of the government, namely the fiscal borrowing and government bonds; Another is the creditor's rights of financial institutions, mainly reflected in rediscount and refinancing, and the increase of this part of assets will create credit creation for deposit-like financial institutions. The liabilities business mainly includes basic currency, issuing bonds, government deposits (government liabilities) and other liabilities. The basic currency includes cash in circulation (the central bank's liabilities for cash holders) and reserve deposits (the liabilities of the central bank for commercial Banks). The correspondence between the items on the balance sheet

\subsubsection{Claims and Liabilities of Financial Institutions}

The central bank's claims to financial institutions include rediscount, various loans, repurchase, etc. The liabilities refer to the central Banks' reserve requirements and excess reserves, which reflect the central bank's funding sources and application of the financial system. When the creditor's right of the financial institution is greater than the liabilities, the increase in the issuance of money can make up the difference; Conversely, it would reduce the circulation of money.

\subsubsection{Claims and Liabilities of the government}

The central bank's claim to the government refers to the total amount of government bonds held by the government and the central bank; The liabilities include financial deposits, reflecting the central bank's source and application of government funds. If the fiscal deficit is too large, the government's debt will be greater than its liabilities. Instead, it would eliminate inflationary pressures from fiscal issuance.

\subsubsection{Foreign Assets and other deposits and their own capital}

Foreign assets consist of foreign exchange reserves, monetary gold, and other foreign assets. If the increase in foreign assets of central Banks corresponds to the increase of other deposits and their own capital, the basic currency will not be affected too much; Conversely, it would increase the domestic base currency (forced to issue). To mitigate the impact on the money supply, the monetary authorities can hedge operations between the relevant projects; Instead, it strengthens operations to increase the role of money supply. The change of the balance sheet of the central bank under the new normal

\subsubsection{Change characteristics of the basic project of the balance sheet}

China's monetary authorities of the balance sheet assets marked characteristics is huge foreign assets accounted for the proportion of total assets, including foreign assets from 162 yuan ( $\$ 54.352$ billion) in 2008 rose to 27.862285 trillion yuan in 2014, weight also rose to $78.49 \%$ from $82.4 \%$, but in 2012 and 2014 in a drop in the proportion of total assets of foreign exchange. The share of financial institutions is on the rise in recent years. The figures show that in the fourth quarter of 2014, the people's bank of China made a total of 500 billion yuan in loans to workers, farmers, middle and middle buildings and five major Banks. 1 trillion yuan of national development bank assets; Another 1 trillion yuan is discounted to small and medium-sized Banks. Corresponding to figure $3-1$, we can clearly see that the foreign exchange and the ratio of creditor's rights to financial institutions are reversed, presenting the characteristics of "this increase in loss".

The number of indebted base currencies has increased year by year, from 12,9222.33 billion yuan in 2008 to 294,09302 million yuan in 2014, and the proportion of the debt has increased from 62.4 percent to 86.9 percent. In terms of the structure of the base currency, the increase was mainly

Volume 6 Issue 12, December 2017 


\section{International Journal of Science and Research (IJSR) \\ ISSN (Online): 2319-7064}

Index Copernicus Value (2016): 79.57 | Impact Factor (2015): 6.391

attributed to financial companies' deposits, which also showed a trend of increasing year by year, from $44.5 \%$ in 2008 to $67.1 \%$ in 2014 . The amount of bonds issued after the financial crisis showed a downward trend (figure 3-2). The outstanding outstanding bonds rose from 29,740.58 billion yuan in 2006 to 45779 in 2008 . It continued to fall to 4049723 million yuan in 2010. The amount of bonds issued by the central bank has been decreasing year by year because of funding costs.

\subsection{Change characteristics of foreign exchange reserves}

\subsubsection{Total Increase}

Although annual growth varies, the total size of foreign exchange reserves is increasing year by year. The state administration of foreign exchange reserves, according to data from the early reform and opening up, China's foreign exchange reserves is only $\$ 1.296$ billion, and 1994 have appeared on the foreign exchange management system reform after the rising trend, at the end of 2006, to the balance of $\$ 853.7$ billion to become the largest holder of global foreign-exchange reserves. As of 2014, China's foreign exchange reserves reached us $\$ 3.84$ trillion.

\subsubsection{Growth Slowdown}

2003-2014, Chinese foreign exchange reserve is roughly showing a downward trend, especially in the 2007 years since the outbreak of the subprime crisis, foreign exchange reserves growth drop degree is most obvious, is down to $0.6 \%$ growth in 2014, individual years fluctuate. In terms of monthly data, the growth momentum of the foreign exchange reserves gradually slowed in the first half of 2014 and started to fall sharply in the second half of the year, with the growth rate of 15 per cent at the beginning of the month falling to 1 per cent at the end of the month.

\subsubsection{Substantial decrease in foreign exchange occupation}

As the central bank buys foreign exchange assets, it is equivalent to putting an equal amount of RMB into the market. Thus, the foreign exchange reserves will decrease as well as the foreign exchange reserves. Figure 3-5 depicts the foreign exchange occupation of central Banks and financial institutions in 2003-2014. Among them, there was a clear trend of "steep decline and steep rise, two-way fluctuation" in 2011-2014. According to the latest monetary authority balance sheet data, in June 2013, total foreign exchange occupation of all financial institutions decreased by 412.5 billion yuan. At the end of September 2014, the balance of the central bank's foreign exchange accounts was 27201791 million yuan, down 13.393 billion yuan from the end of August. As a result, foreign exchange accumulation has fallen off a cliff in the willingness to sell foreign exchange, and the central bank has not been forced to buy foreign exchange as much as it used to, and the underlying currency has less incentive to launch.

3.2.4 The proportion of foreign exchange in the basic currency has declined

Since 2002, the foreign exchange accounts for the proportion of the monetary base is very high, in 2008 and 2009 , this proportion is more than $100 \%, 115.8 \%$ and $121.6 \%$, respectively, show that over the years new on the currency is not only the basis of all contributed by the foreign exchange, must also be by reducing from other channels on the basis of currency to offset the beyond part. In addition, we can see that China's money supply surged from 185000.7 billion yuan in 2002 to 12,2875 billion yuan in 2014, up by nearly 664\%. However, after the 2008 financial crisis, the ratio of foreign exchange occupation to the base currency was slightly lower, with the growth rate of foreign exchange occupying the single digits in 2012 and 2014 , compared with the previous peak of $54 \%$.

Based on the above data, it is not hard to analyze new normal channels of base money has changed, the latest monetary policy report shows that in 2014 the central bank monetary policy tools to supply the monetary base of about 2 trillion yuan, more than 2.1 trillion yuan, compared to the foreign exchange supply base currency of about 640 billion yuan, compared with less increase of 2.1 trillion yuan. Open market operations, refinancing, rediscount and other fluidity support tools to replace the foreign exchange occupation gradually become the main channel of the base money.

\section{The Impact of Low Growth of Foreign Exchange Reserves on Money Supply}

\subsection{The Foreign Exchange Reserve influences the path of money supply}

Central bank assets structure reflects the source of the monetary base, by the central bank balance sheet summary table to analyze the composition of the money supply in China, thus illustrating the conduction path between foreign exchange reserves and money supply, using the basic principle of accounting $\mathrm{NFA}+\mathrm{NDC}+\mathrm{OA}=\mathrm{MB}+\mathrm{LF}+\mathrm{GD}+\mathrm{OL}$ identity, $\mathrm{MB}=\mathrm{NFA}+\mathrm{NDC}+\mathrm{OA}-\mathrm{LF}-\mathrm{GD}-\mathrm{OL}$,

Based on the money supply $=$ the base currency $\mathrm{x}$ money multiplier,

$\mathrm{MS}=\mathrm{m} \mathrm{MB}$

$=\mathrm{m}(\mathrm{NFA}++\mathrm{OA}-\mathrm{LF}-\mathrm{GD}-\mathrm{OL} \mathrm{NDC})$

The NFA $=\mathrm{m}+\mathrm{m}(\mathrm{NDC}-\mathrm{LF}-\mathrm{GD}+\mathrm{OA}-\mathrm{OL})(1)$

In the formula, MS stands for the total amount of money supply, and $\mathrm{m}$ stands for the money multiplier. $\mathrm{M}$ (ndc-lf -GD+OA-OL) is based on the domestic credit channel. The other part of the money supply is caused by the net assets of foreign countries, and the mNFA means that it is not the self-directed launch of the basic currency of the central bank.

Foreign exchange reserves are foreign currency assets acquired in renminbi assets, and foreign exchange is the domestic currency that monetary authorities put into foreign exchange. A large part in our country, the central bank's net assets abroad from the foreign exchange reserves, gold and other foreign assets proportion is very small, especially in 


\section{International Journal of Science and Research (IJSR) \\ ISSN (Online): 2319-7064}

Index Copernicus Value (2016): 79.57 | Impact Factor (2015): 6.391

the 21 st century, our country foreign exchange accounts for the proportion of foreign equity generally maintained at $95 \%$, so foreign exchange can be approximately regarded as net assets abroad. Yan yi Yang [14]

\section{Formula (1) simplifies to $\mathrm{MS}=\mathrm{m} \mathrm{F}+\mathrm{m} \mathrm{D}(2)$}

The increment of money supply can be expressed as delta $\mathrm{MS}=\operatorname{deltamF}+\operatorname{deltamD}(3)$

It is not hard to see from the type on: under the condition of open economy, a country's money supply is affected by changes in foreign exchange reserves, and the influence of the foreign exchange reserves with the increase in a country's foreign economic development. To sum up, the impact of China's foreign exchange reserves on the supply of money can be expressed as: balance of payments surplus, foreign exchange reserves, and the accumulation of foreign exchange reserves, the basic currency, and the supply of money.

\section{2the analysis of factors affecting money supply in low foreign exchange reserve growth}

\subsection{1low growth in foreign exchange reserves and basic currency}

The conversion of foreign exchange reserves and foreign exchange accounts can be simply stated as: the corresponding domestic currency of the bank in the process of acquiring foreign exchange assets is the foreign exchange occupation. Since the reform of the foreign exchange management system in 1994, China has started to implement the compulsory sale of foreign exchange. The system means that companies should sell their surplus foreign exchange to commercial Banks, which then sell them to other commercial Banks or central Banks in the interbank foreign exchange market.

Foreign exchange reserves can eventually form the base currency of the people's bank. As mentioned in the above mentioned $\mathrm{MB}=\mathrm{NFA}+\mathrm{NDC}+\mathrm{OA}-\mathrm{LF}-\mathrm{gdol}$, it is concluded that the base money is actually composed of net domestic credit, net foreign assets and securities issuance. Among them, net domestic credit and net foreign assets can lead to the same change of basic currency, and the issuance of securities can cause the reverse adjustment of basic currency. In the basic monetary structure identity, the last few terms are collectively referred to as domestic credit, which is a way of the central bank to launch the basic currency; Another is the use of foreign exchange reserves to influence the launch of base money, in the form of foreign exchange.

With the current slow growth in foreign exchange reserves, the ratio of foreign exchange in the monetary base is becoming more and more low, as above table 3-1, according to data in 2009 , accounting for $121.6 \%$ of foreign exchange in the monetary base, has dropped to $92.04 \%$ of the total 2014, 2012 and 214, the foreign exchange rate is only $1.84 \%, 2.13 \%$, and up to $53.95 \%$ by 2008 . It seems that no longer high foreign exchange become the main delivery channel of the monetary base in China, in the case of other factors constant, the fall in foreign exchange base currency equivalent.

\subsubsection{Low growth of foreign exchange reserves and the monetary multiplier}

When the main economic entity converts foreign exchange into renminbi, it is deposited in the commercial bank that is exchanged, and forms the liquidity liabilities of commercial Banks, which in turn can be converted into the corresponding assets of commercial Banks. When foreign exchange reserve scale with a lower growth, the formation of foreign exchange is reduced, and economic structure adjustment of our country under the new normal, overall tightening of liquidity, the liquidity of commercial Banks weakened, its loans will also will be reduced, thus will increase the size of the excess deposit reserve and cash assets, eventually lead to the excess deposit reserve rate and cash leakage rate increase, even domestic legal deposit reserve ratio remains unchanged, the money multiplier will be smaller.

\subsubsection{The low growth of foreign exchange reserves and the time lag of the money supply}

According to the central banking knowledge, the monetary base through into the expansion to the whole financial system of a series of transformation of the savings and loan, up to the central bank, commercial Banks this process with a longer transmission delay. The transmission chain of base money is further extended under the uncertainty of the behavior of commercial Banks. But under the bank's foreign exchange settlement system, the foreign exchange reserves can quickly convert the base money into corporate deposits, accelerate the expansion of the money supply, and thus shorten the time lag of the monetary regulation. In the past, high foreign exchange reserves have changed the normal course of monetary transmission, shortening the time lag of transmission. On the contrary, today's low-speed foreign exchange reserves stretch the flow of money supply, slowing the rate of monetary expansion.

From what has been discussed above, under the background of the new normal, because the U.S. economic recovery, the dollar, European recession affect China's export, lead to the trade surplus is abate, capital deficit increase, in addition to the public free hold hui will rise and the internationalisation of the renminbi, China's foreign exchange reserves into the deceleration phase. The low - speed growth of foreign exchange reserves influences the money supply by influencing the base currency, the money multiplier and the time lag of the money supply. Foreign exchange channel on the low growth reserves base currency sharply decrease and the multiplier effect is abate, the two factors together and the money supply delay chain stretched under the comprehensive action of the money supply channel is blocked in China. Monetary policy implementation report 2014 M2 balance is 122.8 trillion yuan, an increase of $12.2 \%$, growth is $1.4 \%$ lower than last year, lower than the central bank about $13 \%$ for all of last year's growth targets, that is has a lot to do with low reserves growth. 


\section{Strategies for Dealing with the Low Growth of Foreign Exchange Reserves}

\subsection{Optimize the Structure of the Central Bank's Balance Sheet}

Foreign exchange reserves, say goodbye to the past continuous high-speed growth will become the norm, the central bank should optimize the structure of the balance sheet, the foreign exchange reserves growth while reduce, but the proportion of total assets and financial company deposit accounts for the proportion of total debt remains high, it will weaken the macroeconomic regulation and control effect of the monetary authorities. Financial firms account for a high proportion is the result of our country for a long time high foreign exchange reserves, resulting from the commercial Banks to sell foreign currency RMB, because most of the foreign exchange are bought by the central bank, its balance sheet assets under a foreign assets will increase, liabilities under commercial bank deposit reserve will also increase, this is equivalent to the people's bank of China to issue currency to increase debt the way of the balance of the balance sheet, thus formed the foreign exchange, eventually led to the monetary base was forced to drop, that the people's bank of China mainly through the financial system to get the money itself, rather than their own money to adjust debt financing. Li Zhongfei [15]

Therefore, we should grasp of foreign exchange reserves growth to bring the favorable opportunity of the balance sheet structure adjustment, in terms of assets, control the number of "foreign currency assets", and the proportion of total assets. Appropriate increase in the proportion of domestic credit and securities investment, through refinancing, directional reduction, open market operation and other means to expand the channel of funds, direct funds to the real economy. On the debt side, gradually increase the proportion of "issuing money" and reduce the proportion of "financial company deposits". For the people's bank of China, the currency issue belongs to the lowest cost, the highest initiative and the most operable source of funds. By increasing "printing money", not only makes the deposit financial institutions create derived monetary ability weakened, can enlarge the space of the central bank monetary policy operation, so as to improve the effect of the monetary authorities macro financial control.

\section{2 dredging the credit transmission channel reduces the time delay effect}

New normal under our country central bank balance sheet presents increasing one minus "two" the characteristics of the asset side of foreign exchange reserves growth fell, the creditor's rights to the government and to slightly increase the proportion of creditor's rights in financial institutions. In spite of this, debt financial company deposit ratio remains high, domestic credit transmission channel is not smooth, it related to many problems existing in the current financial system in our country, commercial Banks to slow the signal of monetary policy, the monetary policy credit channel is blocked in the conduction process of financial institutions. Therefore, we will accelerate reform of the state-owned commercial bank's internal system, establish a modern financial enterprise system at the same time, should also be slow to adapt to the foreign exchange reserves growth trend, making the bank on the monetary base way more diverse, so as to realize the effective transmission of monetary policy.

\subsection{Flexible Use of policy tools to ensure adequate liquidity}

Complying with the new changes of foreign exchange reserve growth is slowing, foreign exchange after reducing domestic base money growth will reduce the pressure of the money supply is determined by the central bank independent, more the central bank is not necessary in order to hedge foreign exchange pressure and raise deposit reserve rate, which will reduce the pressure of commercial Banks, at this time are more likely to promote the reform of interest rate marketization, the interest rate marketization advance will make the small and medium-sized enterprises to obtain more credit resources, which is conducive to economic restructuring. In this context to the monetary authorities to further optimize the monetary base delivery channels, flexible use of MLF (medium term lending facilities), SLF (regular lending facilities), PSL supplement (mortgage loan), and other innovative liquidity adjustment tools, the impact of low growth is slowing foreign exchange reserves to maintain reasonable growth in money supply.

\subsection{To strengthen the impact of the opening of capital projects}

The financial reform of the Shanghai free trade area will pave the way for the internationalization of RMB. In 2015, China will also try to make a trial of RMB capital account convertibility. Opening up the capital account helps domestic companies go out and acquire overseas companies, which will further accelerate the internationalization of RMB. This means that the future of our country no longer need to maintain large foreign exchange reserves to ensure that the payment needs, make our country existing foreign exchange reserves is affected, and change the traditional monetary base on the mechanism, bring opportunities for the monetary authorities to seek new monetary policy tool.

\section{References}

[1] ZhangBin,WangXun.An Analysis of the Determinants of the Changes in China's Foreign Exchange Reserves'Nominal and Real Rates of Return.[J].Social Science in China,2014,Vol.35 (3), pp.65-81Taylor \& Francis

[2] Rangan Gupta, Shawkat Hammoudeh, Won Joong Kim Forecasting China's foreign exchange reserves using dynamic modelaveraging:The role of macroeconomic fundamentals, financial stress and economic uncertainty.[J].North American Journal of Economics and Finance, 2014Elsevier

[3] Pritha Das, Atin Das, Laura Gardini.Investigating 


\section{International Journal of Science and Research (IJSR) \\ ISSN (Online): 2319-7064 \\ Index Copernicus Value (2016): 79.57 | Impact Factor (2015): 6.391}

the Existence of Chaos in Inflation Data in relation to Chaotic Foreign Exchange Rate.[J].Economics Research International,2014,Vol. 2014Hindawi

[4] Yuliya Romanyuk.Liquidity, risk, and return: specifying anobjective function for the management of foreign reserves.[J].Appl. Stochastic Models Bus. Ind. 2012, Vol.28 (3)Wiley

[5] Dianlei Lu, Zhixin Liu.Capital Control, Financial Depth and the Demand of Foreign Reserves: Evidence on 1994-2013 Data in China.[J].Open Journal of Social Sciences,2014,Vol.02 (09), pp.6-11Scientific Research Publishing

[6] Chi-Chur Chao, Li-Ju Chen, Shih-Wen Hu.Stock prices, foreign reserves, and regime collapse.[J].Asia-Pacific Journal of Accounting \& Economics, 2014, Vol.21 (2), pp.207-225Taylor \& Francis

[7] Tun-jen Cheng, Xuan Liu.Foreign exchange reserves: a new challenge to China.[J].Journal of Post Keynesian

Economics, 2013, Vol.35 (4), pp.621-650Taylor \& Francis

[8] Wen Yaping.The Growth Factor Analysis of Chinese Foreign Exchange Reserve Based on Factorial Analysis. [J].Business and Globalization, 2013, Vol.01 (02), pp.9-13

[9] Kathryn M.E. Dominguez.Foreign reserve management during the global financial crisis.[J].Journal of International Money and Finance, 2012, Vol.31 (8), pp.2017-2037Elsevier

[10] Xiaodong Huang.An AHP Model on Currency Structure of Chinese Foreign Exchange Reserves[J].Energy

Procedia, 2011, Vol.13, pp.1140-1147Elsevier

[11] 粟勤, 王少国, 胡正. 外汇占款对我国货币供给的 影响机制研究——基于2000-2012年央行资产负债 表结构变动的分析 $[\mathrm{J}]$. 财经科学, 2013, 10: 11-20.

[12] 王煊. 外汇占款对基础货币影响的实证研究 [J]. 现 代经济信息，2014，03：171-173+184.

[13] 杨艳, 徐丽君. 外汇储备变动对中央银行资产负债 表的影响 [J]. 四川大学学报(哲学社会科学版), 2014, 02: 91-97.

[14] 张开宇. 我国外汇占款规模变动对货币政策影响研 究 $[J]$. 现代财经(天津财经大学学报), 2014, 05: 25-35.

[15] 问少胥, 郝汉蹈. 高额外汇储备对货币供给的影响 及对策 $[\mathrm{J}]$. 现代经济信息，2014，06：5.

\section{Author Profile}

Zhang Sichen received Bachelor's degree from Xidian University, China 